\title{
Effects of Calcium Levels in Artificial Pellet Feed on the Growth and Survival Rate of Black Apple Snails (Pila polita)
}

\author{
Le Van Binh \& Ngo Thi Thu Thao
}

College of Aquaculture and Fisheries, Can Tho University, Can Tho 94115, Vietnam

\begin{abstract}
The present study was conducted to evaluate the effects of different dietary calcium levels on the growth and survival rate of black apple snails (Pila polita) in the grow-out period. There were 3 replicates for each treatment and the snails were fed with five calcium levels (\% dry matter) in diet as follows: 1\% (Ca1), 3\% (Ca3), 5\% (Ca5), 7\% (Ca7), and 9\% (Ca9). Two-month-old juveniles with an average initial body weight of $2.13 \mathrm{~g}$, shell height of $21.71 \mathrm{~mm}$, and shell width of $16.35 \mathrm{~mm}$ were reared in tarpaulin tanks $(1 \times 1 \times 1 \mathrm{~m} ; 40 \mathrm{~cm}$ water depth) at the density of 100 individuals per tank. After 4 months of the rearing period, the average body weight, shell height, and shell width of the snails reached the highest values in the Ca5 treatment $(28.43 \mathrm{~g}, 54.97 \mathrm{~mm}$, and $40.09 \mathrm{~mm}$, respectively) and these values were significantly different compared to the remaining calcium contents ( $\mathrm{Ca} 1, \mathrm{Ca} 3, \mathrm{Ca} 7$, and $\mathrm{Ca} 9)$. The survival rate of the snails in $\mathrm{Ca} 3$ (75.7\%) was higher than in $\mathrm{Ca} 1$ and $\mathrm{Ca} 7$ (74.7\%), $\mathrm{Ca} 5$ $(73.7 \%)$, and $\mathrm{Ca} 9(71.7 \%)$. However, the survival rate was not significantly different among the treatments. Snails in Ca5 obtained the highest productivity $\left(2.88 \mathrm{~kg} \mathrm{~m}^{-2}\right)$ and this value was significantly different from Ca1 $\left(2.55 \mathrm{~kg} \mathrm{~m}^{-2}\right)$ and $\mathrm{Ca} 9\left(2.35 \mathrm{~kg} \mathrm{~m}^{-2}\right)$. The results of this study showed that the growth rate and productivity of black apple snails were highest when they consumed a diet containing 5\% calcium. The optimum requirement of calcium for the black apple snails in the grow-out period was $4.51 \%$.
\end{abstract}

\section{Keywords}

Black apple snail, growth, dietary calcium, survival rate

\section{Introduction}

Mollusks rely on calcium for the growth of their shell and thus, are highly dependent on calcium availability for survival. Harrison

Received: Feburary 13, 2019 Accepted: July 2, 2019

Correspondence to Ivbinh654@gmail.com et al. (1970) already reported the reduced growth rate, survival, and reproductive output of snails in low calcium environments. The most important site of calcium deposition in gastropods is the shell, where it constitutes $97 \%$ of the shell weight (Heller \& Magaritz, 
1983; Marxen \& Becker, 2000). Calcium is also deposited in the digestive gland, connective tissue cells, foot tissue, and around major blood vessels (Tompa \& Watabe, 1976; Marxen \& Becker, 2000). Although shell-building animals in particular need to obtain calcium, it is also required for other functions, including blood clotting, muscle function, and nerve transmission in other animals (Ireland, 1993). Chaitanawisuti et al. (2010) indicated that the calcium needs of species belonging to Gastropoda class are higher than others. Under certain conditions, calcium removed from the shell will lead to edgrowth in some gastropods (Harrison et al., 1970; Tompa \& Watabe, 1976). Besides, the growth and survival of species belonging to Gastropoda are affected when calcium levels decrease or come from a different origin (Oluokun et al., 2005; Egonmwan, 2008; Kouassi, 2008; Badmos et al., 2016; Binh et al., 2017). Dietary calcium is an essential nutrient for the growth, reproduction, and construction of the shell in terrestrial gastropods (Marxen et al., 2003; Egonmwan, 2008; Glass \& Darby, 2009; Dalesman \& Lukowiak, 2013). The growth rate is directly proportional to the concentration of calcium in the diet. Pawson \& Chase (1984) showed that the growth rate of giant African snails (Achatina fulica) is reduced as calcium availability decreases. However, little information concerning the dietary calcium content for black apple snails (Pila polita) is available. From the above issues, an experiment was developed to test different kinds of processed food diets and determine the appropriate calcium content to improve efficiency of the black apple snail grow-out period, while also saving costs and reducing the impact on the water quality in the culture environment.

\section{Materials and Methods}

\section{Experimental design}

The experimental $P$. polita with initial weights ranging from 1.52 to $2.72 \mathrm{~g}$, shell heights from 20.94 to $23.50 \mathrm{~mm}$, and shell widths from 14.47 to $17.34 \mathrm{~mm}$ were nursed in the Cao Lanh district, Dong Thap province $\left(10^{\circ} 20^{\prime} 40,6^{\prime \prime} \mathrm{N} ; \quad 105^{\circ} 47^{\prime} 04,8^{\prime \prime} \mathrm{E}\right), \quad$ Vietnam. Freshwater was pumped from the river to the settling tanks $\left(10 \mathrm{~m}^{3}\right)$ for 7 days and then supplied to the culture tanks.

This experiment included five feeding treatments with different calcium levels and three replicates per treatment as follows: $1 \%$ (Ca1), 3\% (Ca3), 5\% (Ca5), 7\% (Ca7), and 9\% (Ca9). $P$. polita juveniles were cultured in $1 \mathrm{~m}^{2}$ $(1 \times 1 \times 1 \mathrm{~m} ; 40 \mathrm{~cm}$ water depth) tarpaulin tanks at the density of 100 ind. $\mathrm{m}^{-2}$ (Binh et al., 2012; Binh \& Thao, 2018). Two feeding trays (diameters of $20 \mathrm{~cm}$ ) and two nylon bunch substrates (diameters of $50 \mathrm{~cm}$ ) were laid at the bottom of each tank. The experiment was conducted for 4 months. The ingredients used and proximate compositions of the experimental diets are presented in Table 1.

The snails were fed twice a day (at 7:00 and 18:00) with a quantity of $4 \%$ of the average snail body weight in each tank. The water volume in the cultured tanks was renewed $30 \%$ after a cycle of 10 days.

\section{Food preparation}

The experimental diets were formulated into pellets from ingredients including fish meal, soybean meal, wheat flour, soy oil, calcium powder $\left(\mathrm{CaCO}_{3} 99 \%\right.$ - calcium carbonate), vitamin premix, mineral premix, and CMC. The dry ingredients, fish meal, wheat flour, vitamin premix, mineral premix, and $\mathrm{CMC}$, were weighed according to the ratios in Table 1 and mixed well under dry conditions. The soybean meal was cooked, allowed to cool down to a temperature around $40-50^{\circ} \mathrm{C}$, and then mixed with the dry ingredients together with soy oil. After mixing, the mixture was pressed into a pasta machine to make the pellets. After drying in the oven at $60^{\circ} \mathrm{C}$ for $24 \mathrm{~h}$, the pellets were stored in the fridge at $4^{\circ} \mathrm{C}$ for experimental feedings. The proximate compositions of each diet were analyzed and the results (Table 1) showed that the calcium levels were in accordance with the experimental design.

\section{Data collection and sample analysis}

\section{Water quality}

The water temperature in the cultured tanks was recorded twice a day at 7:00 and 14:00 
Table 1. Formulation and proximate compositions of the experimental diets (\% dry matter)

\begin{tabular}{|c|c|c|c|c|c|}
\hline Treatments & Ca1 & $\mathrm{Ca} 3$ & Ca5 & $\mathrm{Ca} 7$ & Ca9 \\
\hline \multicolumn{6}{|l|}{ Ingredient (\%) } \\
\hline Fish meal $^{1}$ & 12.50 & 12.50 & 12.50 & 12.50 & 12.50 \\
\hline Soybean meal ${ }^{2}$ & 22.80 & 22.95 & 23.08 & 23.22 & 23.36 \\
\hline Wheat flour & 58.70 & 56.42 & 54.28 & 52.14 & 49.99 \\
\hline Vegetable oil & 1.00 & 1.00 & 1.00 & 1.00 & 1.00 \\
\hline Vitamins, Minerals ${ }^{3}$ & 3.00 & 3.00 & 3.00 & 3.00 & 3.00 \\
\hline $\mathrm{CMC}^{4}$ & 2.00 & 2.00 & 2.00 & 2.00 & 2.00 \\
\hline Calcium $^{5}$ & 0.00 & 2.13 & 4.14 & 6.14 & 8.15 \\
\hline \multicolumn{6}{|c|}{ Nutrition compositions (\%) } \\
\hline Crude protein & 18.50 & 19.50 & 19.30 & 18.50 & 18.90 \\
\hline Crude lipid & 3.38 & 3.78 & 4.08 & 3.66 & 3.71 \\
\hline NFE & 57.18 & 51.29 & 47.51 & 41.28 & 37.30 \\
\hline Crude ash & 4.46 & 7.91 & 9.08 & 13.34 & 15.73 \\
\hline Crude fiber & 1.61 & 1.62 & 1.33 & 1.70 & 1.45 \\
\hline Moisture & 13.63 & 12.68 & 12.85 & 13.77 & 13.41 \\
\hline Calcium & 0.88 & 2.87 & 5.48 & 7.39 & 9.15 \\
\hline Phosphorus & 0.36 & 0.35 & 0.37 & 0.36 & 0.35 \\
\hline
\end{tabular}

Note: Parameters: Protein, lipid, ash, fiber, moisture, NFE-Nitrogen free extract, and calcium were analyzed by the Quality Assurance and Testing Center Can Tho; ${ }^{1}$ Fish meal Kien Giang (Viet Nam); ${ }^{2}$ Soybean meal (Argentina); ${ }^{3}$ Vitamin premix and mineral premix: Vitamin A, 2,000,000 IU; Vitamin D, 400,000 IU; Vitamin E, 6g; Vitamin B1, 800mg; Vitamin B2, 800mg; Vitamin B12, 2mg; Calcium D. Panthotenate, 2g; Folic acid, 160mg; Vitamin C, 15g; Choline chloride, 100g; Iron (Fe $\left.{ }^{2+}\right)$, 1g; Zinc $\left(\mathrm{Zn}^{2+}\right), 3 g$; Manganese $\left(\mathrm{Mn}^{2+}\right), 2 \mathrm{~g}$; Copper $\left(\mathrm{Cu}^{2+}\right), 100 \mathrm{mg}$; lodine $(\mathrm{I}), 20 \mathrm{mg}$; Cobalt $\left(\mathrm{Co}^{2+}\right), 10 \mathrm{mg} ;{ }^{4}$ Carboxymethyl cellulose; and ${ }^{5} \mathrm{Calcium}$ carbonate powder.

using a thermometer. $\mathrm{pH}$ levels, the concentrations of $\mathrm{NH}_{4}^{+} / \mathrm{NH}_{3}$ (TAN), $\mathrm{NO}_{2}^{-}$, and $\mathrm{DO}$, and alkalinity in the cultured tanks were checked weekly using a Sera test-kit (Made in Germany).

\section{Growth performance and feed utilization}

At day 1 and at 15-day intervals during the experiment, the number of snails in each tank was counted to calculate the survival rate. To determine the growth rate, shell heights and shell widths were measured with an electronic digital caliper $(0.01 \mathrm{~mm})$, and body weights were measured with an electronic scale $(0.01 \mathrm{~g}$ error) for 20 snails per tank.

Weight gain (WG), shell height gain (HG), shell width gain (SWG), daily weight gain (DWG), daily height gain (DHG), specific growth rate for body weight $\left(\mathrm{SGR}_{\mathrm{BW}}\right)$, specific growth rate for shell height $\left(\mathrm{SGR}_{\mathrm{H}}\right)$, specific growth rate for shell width (SGR $\left.\mathrm{SW}_{\mathrm{S}}\right)$, feed conversion ratio (FCR), calcium efficiency ratio (CaER), and survival were calculated using the following equations:

Survival rate $(\%)=$ (Final number of snails/Initial number of snails $) \times 100$

Biomass increase rate $(\mathrm{BIR}, \%)=($ Biomass increase/Biomass initial) $\times 100$

Feed conversion rate $(\mathrm{FCR})=$ Total feed intake (dry weight)/Weight gain (wet weight)

Productivity $\left(\mathrm{P}, \mathrm{kg} \mathrm{m}^{-2}\right)=$ Total snail biomass $(\mathrm{kg})$ per $\mathrm{m}^{2}$ at the end of the experiment

Calcium efficiency ratio $(\mathrm{CaER})=$ Weight gain/Calcium intake

Feed intake $($ FI-mg/ind./day $)=[$ Total feed intake/(Initial number of snails + Final number of snails) $/ 2$ ] $\times$ Days of culture 


\section{Statistical analysis}

The data were analyzed for mean values and standard deviations using Excel software (2016), and one-way ANOVA analysis followed by the Duncan post hoc test was applied to determine significant differences of the collected parameters among the treatments at $\mathrm{P}$ $<0.05$ using the SPSS program version 22.0.

The data on the specific growth rate (SGR ${ }_{\mathrm{W}}, \% /$ day) were subjected to the quadratic regression analysis model (Zeitoun et al., 1976) and the optimal calcium requirement of black apple snails was estimated.

\section{Results and Discussion}

\section{Water quality parameters}

The mean values of the environmental parameters are shown in Table 2. During the experiment, the average temperature remained at $25.3^{\circ} \mathrm{C}$ in the morning and ranged from $27.5^{\circ} \mathrm{C}$ to $27.8^{\circ} \mathrm{C}$ in the afternoon, with daily fluctuations around $2.6^{\circ} \mathrm{C}\left(0.5-4.7^{\circ} \mathrm{C}\right.$; Figure 1). There were no significant differences in temperature among the treatments.

$\mathrm{pH}$ levels in all the treatments were in the range of 7.94-8.06. The highest $\mathrm{pH}$ was measured in $\mathrm{Ca} 9$ (8.06) and this value was not significantly different to those in $\mathrm{Ca} 5$ or $\mathrm{Ca} 7$. In addition, there were no significant differences among the $\mathrm{pH}$ values of 7.94, 7.96, and 8.01 for the treatments $\mathrm{Ca} 1, \mathrm{Ca} 3$, and $\mathrm{Ca} 5$, respectively.
DO levels varied slightly among the treatments (4.58-4.63 $\mathrm{mgO}_{2} \mathrm{~L}^{-1}$ ), and no significant differences were found.

The alkalinity value in Ca1 $(67.6 \mathrm{mg}$ $\mathrm{CaCO}_{3} \mathrm{~L}^{-1}$ ) was the lowest, and was significantly different compared to the values for $\mathrm{Ca} 3, \mathrm{Ca} 7$, and $\mathrm{Ca} 9$. The concentrations of TAN and $\mathrm{NO}_{2}{ }^{-}$varied from 0.65 to $0.74 \mathrm{mg} \mathrm{L}^{-1}$ and from 0.59 to $0.73 \mathrm{mg} \mathrm{L}^{-1}$, respectively. $\mathrm{Ca} 5$ showed the highest value of TAN $\left(0.74 \mathrm{mg} \mathrm{L}^{-1}\right)$, but there was no significant difference with the other treatments. The value of $\mathrm{NO}_{2}^{-}$in $\mathrm{Ca} 5$ $\left(0.73 \mathrm{mg} \mathrm{L}^{-1}\right)$ was higher than in the other treatments.

\section{Growth performance of black apple snails}

The average body weights, shell heights, and shell widths of $P$. polita fed formulated diets with different concentrations of calcium for four months are illustrated in Table 3. The snails reached the highest values of these three traits in Ca5 $(28.43 \mathrm{~g}, 54.97 \mathrm{~mm}$, and $40.09 \mathrm{~mm}$, respectively) which were significantly different from the values in the other treatments.

The results also indicated that the daily weight gain and specific growth rate were highest in the $\mathrm{Ca} 5$ treatment $(0.22 \mathrm{~g} /$ day and $2.17 \% /$ day, respectively), and lowest in $\mathrm{Ca} 9$ ( $0.18 \mathrm{~g} /$ day and $2.02 \%$ /day, respectively).

Significant differences for these traits were detected among the treatments. Similarly, the highest daily height gain and specific growth

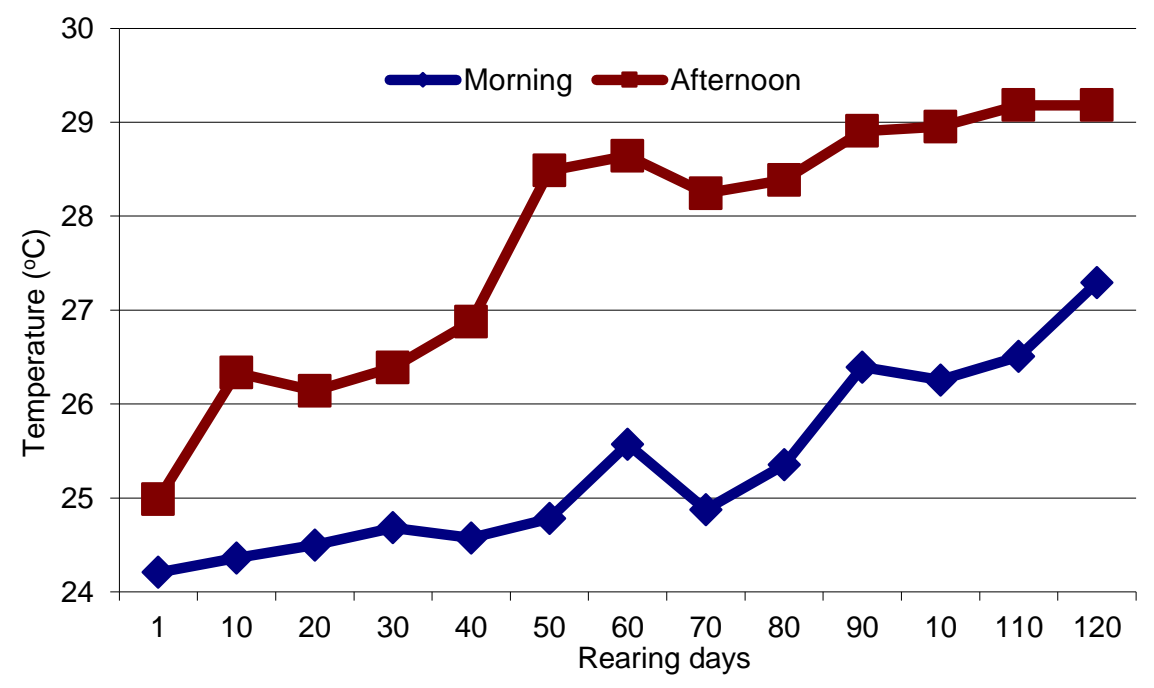

Figure 1. Fluctuations in the morning and afternoon temperatures during the experimental period 
Table 2. Mean values of the environmental parameters during the experimental period

\begin{tabular}{|c|c|c|c|c|c|c|}
\hline \multicolumn{2}{|c|}{ Diets } & Ca1 & $\mathrm{Ca} 3$ & Ca5 & $\mathrm{Ca} 7$ & Ca9 \\
\hline \multicolumn{2}{|c|}{ Calcium levels (\%DM) } & 1 & 3 & 5 & 7 & 9 \\
\hline \multirow{2}{*}{ Temperatue $\left({ }^{\circ} \mathrm{C}\right)$} & Morning & $25.3^{a} \pm 1.0$ & $25.3^{a} \pm 1.0$ & $25.3^{a} \pm 0.9$ & $25.3^{a} \pm 1.0$ & $25.3^{a} \pm 0.9$ \\
\hline & Afternoon & $27.6^{a} \pm 1.6$ & $27.6^{a} \pm 1.4$ & $27.8^{\mathrm{a}} \pm 1.4$ & $27.5^{a} \pm 1.6$ & $27.5^{\mathrm{a}} \pm 1.5$ \\
\hline \multicolumn{2}{|l|}{$\mathrm{Oxy}\left(\mathrm{mg} \mathrm{O}_{2} \mathrm{~L}^{-1}\right)$} & $4.61^{a} \pm 0.28$ & $4.63^{a} \pm 0.31$ & $4.61^{a} \pm 0.26$ & $4.63^{a} \pm 0.26$ & $4.58^{a} \pm 0.22$ \\
\hline \multicolumn{2}{|l|}{$\mathrm{pH}$} & $7.94^{\mathrm{a}} \pm 0.32$ & $7.96^{\mathrm{ab}} \pm 0.24$ & $8.01^{\mathrm{abc}} \pm 0.28$ & $8.03^{b c} \pm 0.23$ & $8.06^{c} \pm 0.21$ \\
\hline \multicolumn{2}{|l|}{ TAN (mg L-1) } & $0.65^{a} \pm 0.10$ & $0.71^{\mathrm{a}} \pm 0.11$ & $0.74^{a} \pm 0.11$ & $0.72^{a} \pm 0.01$ & $0.66^{a} \pm 0.07$ \\
\hline \multicolumn{2}{|l|}{$\mathrm{NO}_{2}^{-}\left(\mathrm{mg} \mathrm{L}^{-1}\right)$} & $0.59^{\mathrm{a}} \pm 0.03$ & $0.66^{b} \pm 0.03$ & $0.73^{c} \pm 0.02$ & $0.67^{d} \pm 0.02$ & $0.69^{\mathrm{bc}} \pm 0.01$ \\
\hline \multicolumn{2}{|c|}{ Alkalinity $\left(\mathrm{mgCaCO}_{3} \mathrm{~L}^{-1}\right)$} & $67.6^{a} \pm 1.1$ & $71.5^{\mathrm{bc}} \pm 2.5$ & $70.2^{\mathrm{ab}} \pm 1.0$ & $74.2^{\mathrm{cd}} \pm 1.7$ & $75.2^{c} \pm 2.6$ \\
\hline
\end{tabular}

Note: The mean values in the same row with different letters indicate significant differences $(P<0.05)$.

Table 3. Mean $( \pm$ SE) growth rates of black apple snails fed on different calcium levels

\begin{tabular}{|c|c|c|c|c|c|}
\hline Diets & Ca1 & Ca3 & Ca5 & $\mathrm{Ca} 7$ & Ca9 \\
\hline Calcium level (\% DM) & 1 & 3 & 5 & 7 & 9 \\
\hline \multicolumn{6}{|c|}{ Body weight } \\
\hline Initial (g) & $2.11^{\mathrm{a}} \pm 0.01$ & $2.14^{\mathrm{a}} \pm 0.05$ & $2.10^{\mathrm{a}} \pm 0.06$ & $2.14^{\mathrm{a}} \pm 0.07$ & $2.15^{\mathrm{a}} \pm 0.03$ \\
\hline Final $(g)$ & $25.47^{b} \pm 0.30$ & $27.21^{d} \pm 0.22$ & $28.43^{\mathrm{e}} \pm 0.35$ & $26.47^{c} \pm 0.33$ & $24.20^{\mathrm{a}} \pm 0.56$ \\
\hline$W G(g)$ & $23.36^{b} \pm 0.30$ & $25.07^{d} \pm 0.17$ & $26.33^{e} \pm 0.40$ & $24.33^{c} \pm 0.26$ & $22.04^{a} \pm 0.57$ \\
\hline DWG (g/day) & $0.19^{b} \pm 0.00$ & $0.21^{c} \pm 0.00$ & $0.22^{d} \pm 0.00$ & $0.20^{\mathrm{bc}} \pm 0.00$ & $0.18^{a} \pm 0.00$ \\
\hline $\mathrm{SGR}_{\mathrm{BW}}(\% /$ day $)$ & $2.08^{b} \pm 0.01$ & $2.12^{\mathrm{c}} \pm 0.01$ & $2.17^{d} \pm 0.03$ & $2.10^{b c} \pm 0.02$ & $2.02^{\mathrm{a}} \pm 0.02$ \\
\hline \multicolumn{6}{|c|}{ Shell height } \\
\hline Initial (mm) & $21.61^{a} \pm 0.13$ & $21.75^{a} \pm 0.08$ & $21.74^{a} \pm 0.09$ & $21.72^{a} \pm 0.19$ & $21.75^{a} \pm 0.10$ \\
\hline Final (mm) & $52.73^{b} \pm 0.15$ & $53.93^{c} \pm 0.63$ & $54.97^{d} \pm 0.58$ & $53.29^{b c} \pm 0.37$ & $51.69^{a} \pm 0.27$ \\
\hline $\mathrm{HG}(\mathrm{mm})$ & $31.12^{b} \pm 0.03$ & $32.18^{c} \pm 0.67$ & $33.23^{d} \pm 0.62$ & $31.57^{b c} \pm 0.25$ & $29.94^{a} \pm 0.35$ \\
\hline $\mathrm{DLG}(\mathrm{mm} / \mathrm{day})$ & $0.26^{b} \pm 0.00$ & $0.27^{c} \pm 0.01$ & $0.28^{d} \pm 0.01$ & $0.26^{b} \pm 0.00$ & $0.25^{\mathrm{a}} \pm 0.00$ \\
\hline $\mathrm{SGR}_{\mathrm{L}}(\% /$ day $)$ & $0.74^{b} \pm 0.00$ & $0.76^{\mathrm{bc}} \pm 0.01$ & $0.77^{c} \pm 0.01$ & $0.75^{\mathrm{b}} \pm 0.00$ & $0.72^{\mathrm{a}} \pm 0.01$ \\
\hline \multicolumn{6}{|c|}{ Shell width } \\
\hline Initial (mm) & $16.27^{a} \pm 0.05$ & $16.34^{\mathrm{a}} \pm 0.06$ & $16.38^{a} \pm 0.23$ & $16.37^{a} \pm 0.13$ & $16.40^{\mathrm{a}} \pm 0.09$ \\
\hline Final (mm) & $38.17^{b} \pm 0.06$ & $39.25^{c} \pm 0.48$ & $40.09^{d} \pm 0.64$ & $38.66^{b c} \pm 0.11$ & $37.32^{a} \pm 0.23$ \\
\hline SWG $(\mathrm{mm})$ & $21.89^{\mathrm{b}} \pm 0.05$ & $22.91^{c d} \pm 0.43$ & $23.72^{d} \pm 0.86$ & $22.29^{b c} \pm 0.07$ & $20.93^{a} \pm 0.23$ \\
\hline DWG (mm/day) & $0.18^{b} \pm 0.00$ & $0.19^{\mathrm{cd}} \pm 0.01$ & $0.20^{d} \pm 0.01^{d}$ & $0.19^{b c} \pm 0.00$ & $0.17^{\mathrm{a}} \pm 0.00$ \\
\hline $\mathrm{SGR}_{\mathrm{Sw}}(\% /$ day $)$ & $0.71^{b} \pm 0.02$ & $0.73^{b c} \pm 0.02$ & $0.75^{c} \pm 0.02$ & $0.72^{\mathrm{b}} \pm 0.01$ & $0.69^{a} \pm 0.01$ \\
\hline
\end{tabular}

Note: The mean values in the same row with different letters indicate the significant differences $(P<0.05)$.

rate for shell height were observed in the $\mathrm{Ca} 5$ treatment and showed significant differences with the other treatments.

The specific growth rates for body weight (SGR $\mathrm{SW}_{\mathrm{BW}}, \% /$ day) of the snails were fitted into quadratic models (Figure 2). The best fit for the estimation of the optimal calcium level could be described as:

$$
\mathrm{Y}=-0.0067 \mathrm{x}^{2}+0.0602 \mathrm{x}+2.0173, \mathrm{R}^{2}=0.9295
$$

where $\mathrm{Y}$ is the $\mathrm{SGR}_{\mathrm{BW}}$ and $\mathrm{x}$ is the percentage of dietary calcium. The trend of the growth curve showed that the $\mathrm{SGR}_{\mathrm{BW}}$ reached 
the maximum value $(2.154 \% /$ day $)$ when the diet contained $4.51 \%$ calcium.

Survival rate, biomass increase rate, productivity, feed conversion rate, and calcium efficiency ratio of black apple snails

The survival rate of the snails in all the treatments decreased gradually during the 4 months of culture (Figure 3) and was not significantly different among treatments, with values in the range of 71.7 to $75.7 \%$.
The biomass increasing rate and productivity reached their maximum values in the Ca5 treatment $\left(640 \%\right.$ and $2.88 \mathrm{~kg} \mathrm{~m}^{-2}$, respectively) and these values were significantly different compared to the other treatments. Meanwhile, the $\mathrm{Ca} 9$ treatment had the lowest values (544\% and $2.35 \mathrm{~kg} \mathrm{~m}^{-2}$, respectively).

The FCR values ranged from 1.22 to 1.39 . The Ca3 treatment had the lowest FCR value (1.22) which was not significantly different from the values of $\mathrm{Ca} 1, \mathrm{Ca} 5$, and $\mathrm{Ca} 7$ (Table 4).

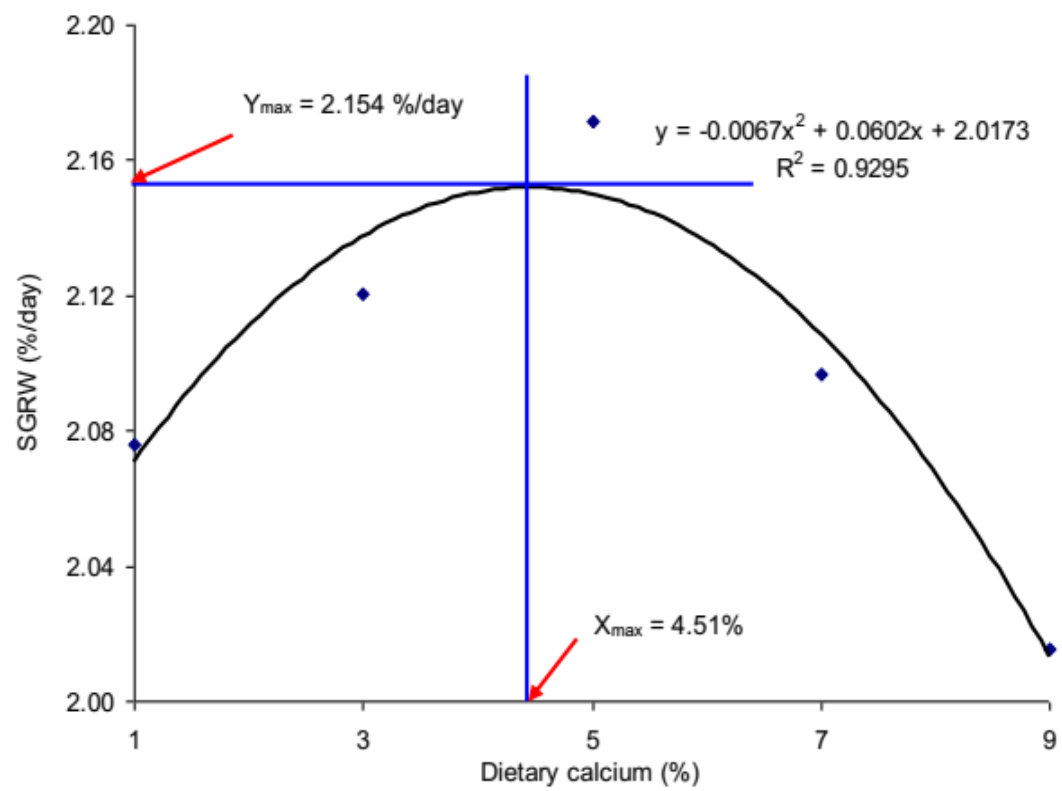

Figure 2. Relationship between the specific growth rate for body weight $\left(\mathrm{SGR}_{\mathrm{BW}}\right)$ and dietary calcium levels (\%DM) for black apple snails $(P$. polita)

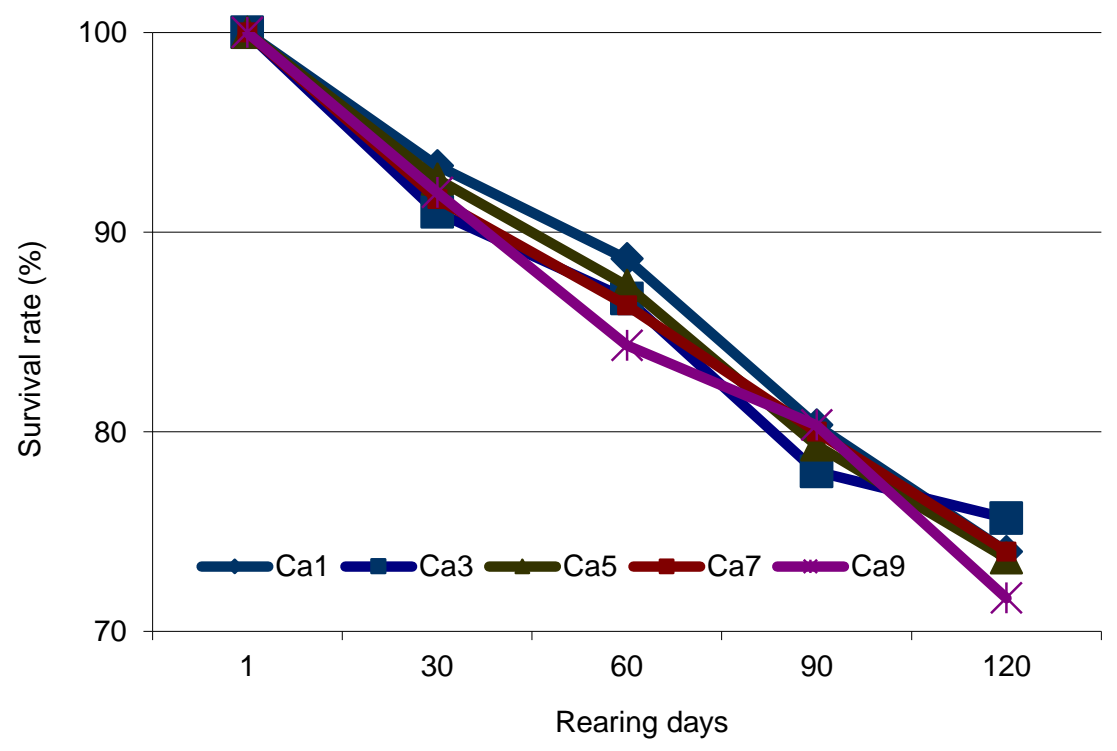

Figure 3. Survival rate of black apple snails during the experiment period 
The highest CaER value was recorded in the Ca1 treatment $(2343 \%)$ and was significantly different compared to $\mathrm{Ca} 3(868 \%)$, Ca5 (534\%), Ca7 (354\%), and Ca9 (237\%). The FI values varied from 302 to $331 \mathrm{mg} /$ ind./day and the $\mathrm{Ca} 9$ treatment presented the lowest FI value (302 mg/ind./day) (Table 5).

\section{Discussion}

The $\mathrm{pH}$ and alkalinity levels increased as the calcium levels increased due to the higher calcium content of the treatments. The calcium source was from $\mathrm{CaCO}_{3}$. Ions of $\mathrm{Ca}^{2+}$ were absorbed by the snails for the growth of their shells and then ions of $\mathrm{CO}_{3}{ }^{2-}$ were released into the water which led to the increase in alkalinity as the calcium level increased. According to Binh et al. (2017) and Thao \& Binh (2017), the mean values of alkalinity ranged from 60.1-71.9 $\mathrm{mg} \mathrm{L}^{-1}$ when rearing snails with different calcium contents. In addition, Glass \& Darby (2009) and Dalesman \& Lukowiak (2013) suggested that fast-growing species of snails will have a greater demand for calcium to support shell formation, resulting in a lower alkalinity of the nursing environment.

The goal of this study was to determine the optimum level of calcium in the diet that would maximize the growth of black apple snails. Our results showed that the weight gain of black apple snails increased when the calcium levels increased from 1 to $5 \%$, and then decreased as the calcium levels continued to increase from 5 to $9 \%$. These results are similar to those in other Gastropoda species (Coote et al., 1996; Briers, 2003; Oluokun et al. 2005; Egonmwan, 2008; Chaitanawisuti et al., 2010; Badmos et al., 2016; Binh et al., 2017; Thao \& Binh, 2017). The best growth was observed in black apple snails fed a diet with $5 \%$ calcium content.

Brodersen \& Madsen (2003) reported that snails raised at lower calcium concentrations were significantly smaller than snails raised at higher concentrations. Egonmwan (2008) found that after 30 weeks of culture, the mean weight and shell length of Limicolaria flammea fed food containing calcium carbonate were $1150 \mathrm{mg}$ and $20.75 \mathrm{~mm}$, respectively, which were significantly higher than the others fed with no calcium $(950 \mathrm{mg}$ and $17.5 \mathrm{~mm}$, respectively). Oluokun et al. (2005) indicated that Archachatina marginata fed a diet with $8 \%$ calcium had the highest mean weight $(234 \mathrm{~g})$, while those fed with $4 \%$ calcium had the lowest mean weight (198g). Similarly, Adou et al. (2011) showed that with the diet containing $12.02 \%$ calcium, Achatina achatina increased in body weight up to $96.78 \mathrm{~g}$ and had a low rate of cumulative mortality (11\%) compared to the $14 \%$ calcium diet $(73.03 \mathrm{~g}$ and $12 \%$,

Table 4. Survival rate (SR), biomass increasing rate (BIR), and productivity $(\mathrm{P})$ of black apple snails fed on different calcium levels

\begin{tabular}{|c|c|c|c|c|c|}
\hline Diets & Ca1 & $\mathrm{Ca} 3$ & Ca5 & $\mathrm{Ca} 7$ & Ca9 \\
\hline Calcium level (\% DM) & 1 & 3 & 5 & 7 & 9 \\
\hline SR (\%) & $74.0^{a} \pm 2.6$ & $75.7^{a} \pm 2.5$ & $73.7^{\mathrm{a}} \pm 2.9$ & $74.0^{\mathrm{a}} \pm 4.4$ & $71.7^{\mathrm{a}} \pm 6.0$ \\
\hline $\mathrm{BIR}(\%)$ & $594^{\mathrm{ab}} \pm 22$ & $600^{\mathrm{ab}} \pm 10$ & $640^{b} \pm 17$ & $593^{\mathrm{ab}} \pm 30$ & $544^{a} \pm 52$ \\
\hline$P\left(\mathrm{~kg} \mathrm{~m}^{-2}\right)$ & $2.55^{\mathrm{ab}} \pm 0.12$ & $2.82^{\mathrm{bc}} \pm 0.12$ & $2.88^{c} \pm 0.12$ & $2.69^{b c} \pm 0.17$ & $2.35^{\mathrm{a}} \pm 0.19$ \\
\hline
\end{tabular}

Note: The values in the same row with different letters indicate the significant differences $(P<0.05)$.

Table 5. Feed conversion ratio (FCR), calcium efficiency ratio (CaER), and feed intake ( $F I)$ of black apple snails fed on different calcium levels

\begin{tabular}{lccccc}
\hline \multicolumn{1}{c}{ Diets } & Ca1 & Ca3 & Ca5 & Ca7 & Ca9 \\
\hline Calcium level (\% DM) & 1 & 3 & 5 & 7 & 9 \\
\hline FCR & $1.34^{\mathrm{ab}} \pm 0.10$ & $1.22^{\mathrm{a}} \pm 0.05$ & $1.24^{\mathrm{a}} \pm 0.06$ & $1.27^{\mathrm{ab}} \pm 0.05$ & $1.39^{\mathrm{b}} \pm 0.03$ \\
$\mathrm{CaER}(\%)$ & $2343^{\mathrm{e}} \pm 116$ & $868^{\mathrm{d}} \pm 37$ & $534^{\mathrm{c}} \pm 24$ & $354^{\mathrm{b}} \pm 24$ & $237^{\mathrm{a}} \pm 21$ \\
$\mathrm{Fl}$ (mg/ind./day) & $315^{\mathrm{b}} \pm 4$ & $322^{\mathrm{bc}} \pm 5$ & $331^{\mathrm{c}} \pm 6$ & $317^{\mathrm{b}} \pm 2$ & $302^{\mathrm{a}} \pm 11$ \\
\hline
\end{tabular}

Note: The mean values in the same row with different letters indicate the significant differences $(P<0.05)$. 
respectively) and the $16 \%$ calcium diet $(76.75 \mathrm{~g}$ and $13 \%$, respectively). Aman et al. (2011) revealed that using oyster shell powder, which contains calcium, as the substrate could affect the growth of the snail Archachatina marginata. When the substrates were amended with $30 \%$ oyster shell powder with a calcium content of $7.7 \%$, the bodyweight growth was $0.86 \mathrm{~g} /$ day and the shell growth was $0.39 \mathrm{~mm} /$ day. This value decreased when the amount of oyster shell powder was reduced. In Babylonia areolate, Chaitanawisuti et al. (2010) demonstrated that a diet supplemented with $7 \%$ calcium resulted in spotted Babylon snails that had a significantly higher specific growth rate for length $(0.37$ $\% /$ day) than those fed diets supplemented with $4 \%$ calcium $(0.32 \% /$ day $)$. Numerous studies have previously demonstrated the importance of calcium as a factor determining the development and wellbeing of snails.

Our findings showed that snails in the experiment had a good growth trend compared to previous studies. The results of this study and previous studies have shown that freshwater gastropods (Pila polita, Pomacea paludosa, Achatina achatina, and Limicolaria flammea) require a diet higher in calcium content than marine species (Babylonia areolata and Huliotis laenigata). A diet with levels of calcium in a suitable range will ensure optimum growth. However, if the content of calcium exceeded the body's needs, then the growth rate of the snail would decrease (Coote et al., 1996; Oluokun et al., 2005; Kritsanapuntu et al., 2006; Chaitanawisuti et al., 2010; Badmos et al., 2016; Binh et al., 2017).

The survival rate of black apple snails after four months of culture ranged from 71.7 to $75.7 \%$ and there were no significant differences among the treatments. Ireland (1990) found that during four months culturing Achatina fulica, mortality was low and occurred in snails on the lower calcium diets. Chaitanawisuti et al. (2010) reported that the survival rate of Babylonia areolate with different levels of dietary calcium $(1 \%, 4 \%$, and $7 \%)$ did not affect survival (91.0-94.9\%).

The biomass increasing rate (BIR) was highest in the $5 \%$ calcium diet $(640 \%)$. This result was comparable to that of Binh \& Thao (2018) who found the BIR was 436-511\%. The productivity of black apple snails after four months of culture was in the range of 2.35-2.88 $\mathrm{kg} \mathrm{m}^{-2}$, similar with the study results of Binh \& Thao (2017) and (2018) who measured productivity to be $2.31-3.15 \mathrm{~kg} \mathrm{~m}^{-2}$ at the snail density of 100 ind $\mathrm{m}^{-2}$ when feeding with pellets (18\% protein; $2.4 \%$ calcium).

The calcium efficiency rate (CaER) of black apple snails decreased as the calcium level in the diet increased. Our study found that the FCR of black apple snails increased when the calcium levels increased from $5 \%$ to $9 \%$. Chaitanawisuti et al. (2010) demonstrated that Babylonia areolate fed with a $4 \%$ calcium diet had an FCR value (2.47) lower than those fed with a $7 \%$ calcium diet (2.76). Oulokun et al. (2005) studied Archachatina marginata and found that the FCR was highest (6.49) when the snails were fed a diet with a $4 \%$ calcium content and tended to decrease when the calcium content increased to 6\% (5.36) and 8\% (5.25). The feed intake (FI) of black apple snails increased as the calcium level increased from 1 to $5 \%$ and then decreased when calcium level increased to $9 \%$. The explanation for this is related to the amount of calcium absorbed by the snails. With a diet of 5\% calcium content, black apple snails had the highest growth rate and then the rate started to decrease as the calcium level increased.

\section{Conclusions}

The concentration of calcium in the diet did not affect the survival rate of black apple snails during the culture period.

After 4 months of culture, the growth of black apple snails (Pila polita) had maximum values in terms of body weight, shell height, and shell width when the snails were fed a diet containing $5 \%$ calcium.

The addition of calcium levels to $5 \%$ to the total diet of black apple snails (Pila polita) would be beneficial in terms of weight gain and productivity. The estimation for the optimum requirement of calcium for black apple snail growth was $4.51 \%$ dry matter of total diet. 


\section{Acknowledgements}

The authors would like to thank Nguyen Thi Ngan Son, Le Thi Hong Tuoi, and Phung Huu Tam for their help during the experiment.

\section{References}

Adou C., Kouassi D., Karamoko M. \& Octchoumou A. (2011). The raising of the edible snails of Africa: food effects of the quality of the diet and the rate of calcium on the performances of growth of Achatina achatina (linné, 1750). Revue du Cames: Science de la santé. 12(1): 6-11.

Aman J. B., Kouassi K. D., Karamoko M. \& Otchoumou A. (2011). Effect of oyster shell powder content in rearing substrate on Archachatina marginata growth. Journal of Applied Biosciences. 47: 3205-3213 (in French with English abstract). Retrieved from http://www.m.elewa.org/JABS/2011/47/2.pdf on October 5, 2018.

Badmos A. A., Sola-Ojo F. E., Oke S. A., Amusa T. O., Amali H. E. \& Lawal A. O. (2016). Effect of different sources of dietary calcium on the carcass and sensory qualities of giant African land snails (Archachatina marginata). Nigerian Journal of Agriculture. Food and Environment. 12(2): 181-184.

Binh L. V. \& Thao N. T. T. (2018). Effects of protein levels in artificial pellet feed on growth and survival rate of black apple snail (Pila polita). International Journal of Scientific and Research Publications. 8(3): 20-26 (in Vietnamese with English abstract).

Binh L. V., Thao N. T. T. \& Tuan N. A. (2017). Determination of dietary calcium in the diet for black apple snail (Pila polita) at juveniles. Vietnam Agricultural Science Journal. 5(10): 1339-1347 (in Vietnamese with English abstract).

Binh N. T., Binh T. T. \& Minh M. D. (2012). The effect of diets and stocking densities on growth and survival of black apple snail (Pila polita). Science and Technology Journal of Agriculture and Rural Development. 1(12): 57-61 (in Vietnamese with English abstract).

Briers R. A. (2003). Range size and environmental calcium requirements of British freshwater gastropods. Global Ecology and Biogeography. 12(1): 47-51.

Brodersen J. \& Madsen H. (2003). The effect of calcium concentration on the crushing resistance, weight and size of Biomphalaria sudanica (Planorbidae). Hydrobiologia. 490: 181-186.

Chaitanawisuti N., Sungsirin T. \& Piyatiratitivorakul S. (2010). Effects of dietary calcium and phosphorus supplementation on the growth performance of juvenile spotted babylon Babylonia areolata culture in a recirculating culture system. Aquaculture International. 18(3): 303-313.
Coote T. A., Hone P. W., Kenyon R. \& Maguire G. B. (1996). The effect of different combinations of dietary calcium and phosphorus on the growth of juvenile Haliotis laevigata. Aquaculture. 145: $267-$ 279.

Dalesman S. \& Lukowiak K. (2013). Effect of acute exposure to low environmental calcium on respiration and locomotion in Lymnaea stagnalis. The Journal of Experimental Biology. 213: 1471-1476.

Egonmwan R. I. (2008). Effects of dietary calcium on growth and oviposition of the African land snail Limicolaria flammea (Achatinidae). Revista de Biología Tropical. 56(1): 333-343.

Glass N. H. \& Darby P. C. (2009). The effect of calcium and $\mathrm{pH}$ on Florida apple snail, Pomacea paludosa, shell growth and crush weight. Aquatic Ecology. 43: 1085-1093.

Harrison A. D., Williams N. V. \& Greig G. (1970). Studies on the effects of calcium bicarbonate concentrations on the biology of Biomphalaria pfeifferi. Hydrobiologia. 36: 317-327.

Heller J. \& Magaritz M. (1983). From where do land snails obtain the chemicals to build their shells. Journal of Molluscan Studies. 49(2): 116-121.

Ireland M. P. (1990). The effect of dietary calcium on growth, shell thickness and tissue calcium distribution in the snail Achatina fulica. Comparative Biochemistry and Physiology - Part A: Molecular and Integrative Physiology. 98(1): 111-116.

Ireland M. P. (1993). The effect of diamox at two dietary calcium levels on growth, shell thickness and distribution of $\mathrm{Ca}, \mathrm{Mg}, \mathrm{Zn}, \mathrm{Cu}, \mathrm{P}$ in the tissues of the snail Achatina fulica. Comparative Biochemistry and Physiology Part C: Comparative Pharmacology. 104(1): 21-28.

Kouassi K. D. (2008). Effect of feeding and rearing substrate on the biological performance of Archachatina ventricosa and some aspects of giant snail collection in Côte d'Ivoire. PhD Thesis Natural Sciences in Biology and Animal Productions. Université d'Abobo - Adjamé, Abidjan Côte d'Ivoire. 130 pages (in French).

Kritsanapuntu S., Chaitanawisuti N., Santhaweesuk W. \& Natsukari Y. (2006). Combined effects of water exchange regimes and calcium carbonate additions on growth and survival of hatchery-reared juvenile spotted Babylon (Babylonia areolata) in recirculating grow-out system. Aquaculture Research. 37: 664-670.

Marxen J. C. \& Becker W. (2000). Calcium binding constituents of the organic shell matrix from the freshwater snail Biomphalaria glabrata. Comparative Biochemistry and Physiology Part B - Biochemistry and Molecular Biology. 127: 235-242.

Marxen J. C., Becker W., Finke D., Hasse B. \& Epple M. (2003). Early mineralization in Biomphalaria glabrata: microscopic and structural results. Journal of Molluscan Studies. 69: 113-121. 
Oluokun J. A., Omole A. J. \& Fapounda O. (2005). Effects of increasing the level of calcium supplementation in the diets of growing snail on performance characteristics. Research Journal of Agriculture and Biological Sciences. 1(1): 76-79.

Pawson P. A. \& Chase R. (1984). The life-cycle and reproductive activity of Achatina fulica (bowdich) in laboratory culture. Journal of Molluscan Studies. 50(2): 85-91.
Thao N. T. T. \& Binh L. V. (2017). Effectiveness of calcium supplementation into diet in rearing juvenile snail, Pila polita. Can Tho University Journal of Science. 52b: 70-77 (in Vietnamese with English abstract).

Tompa A. S. \& Watabe N. (1976). Calcified arteries in a gastropod. Calcified Tissue Research. 22(2): 159-172.

Zeitoun I., Ullrey H. D. E. \& Magee W. T. (1976). Quantifying nutrient requirements of fish. Journal of the Fisheries Research Board of Canada. 33: 167-172. 